\title{
Eosinophilia in Children with Single and Mixed Soil Transmitted Helminthiasis
}

\author{
Yoan Carolina Panggabean ${ }^{1}$, Sri Wahyuni Nasution ${ }^{2}$, Lambok Siahaan $^{3}$, Ayodhia Pitaloka Pasaribu ${ }^{4}$ \\ ${ }^{1,3}$ Department of Parasitology Medical Faculty, University of Sumatera Utara, Indonesia \\ carolina_yoan@yahoo.com ${ }^{1}$ \\ lambok_fkusu@yahoo. $\mathrm{com}^{3}$ \\ ${ }^{2}$ Medical Student of Tropical Disease Medical Faculty, University of Sumatera Utara, Indonesia \\ sriwahyuni_nst88@yahoo.com² \\ ${ }^{4}$ Department of Paediatry Medical Faculty, University of Sumatera Utara, Indonesia \\ ayodhia_pitaloka@yahoo.com
}

\begin{abstract}
Worldwide, helminths infections are by far the leading cause of infection associated-eosinophilia and probably of eosinophilia of all causes. Due to behavioral aspects, partial immunity and other factors, prevalence rates and infection intensity are usually highest in children. Consequently, eosinophilia is common in tropical developing countries. Population based study in rural areas has demonstrated eosinophilia in up to $50 \%$ in children and adults. The objective of this study was to determine eosinophilia in children with Soil Transmitted Helminthiasis (STHs) of SD Panti Asuhan AlJamiyatul Washliyah Pulo Brayan Medan. This was an observational study with cross-sectional approach. In this study, 82 children with STH enrolled. They are divided into two groups single and mixed STHs. All children were examined for eosinophilia. The results showed 40 children $(48,8 \%)$ with single STHs; 42 children $(51,2 \%)$ with mixed STH. The intensity of STHs were light infection $89 \%$, moderate $7,3 \%$ and heavy infection $3,7 \%$. Eosinophilia was found with mean $6,86 \%$ with SD 3,93 on single STHs and $10,12 \%$ with SD 6,34 on mixed STHs. It suggested that eosinophilia was higher on mixed STHs than single STH infection. Helminthic infection should be considered an important cause of eosinophilia. The absence of eosinophilia cannot exclude these parasites. However, the incidence and extent of infection related eosinophilia do not depend only on the type, intensity and stage of infection; other factors such as individual differences in innate and adaptive immune responses, epidemiological background, age at first exposure, underlying conditions, etc are important as well. There was a significant difference of eosinophil value between single and mixed STHs on children of SD Panti Asuhan Al-Jamiyatul Washliyah Pulo Brayan Medan. Eosinophilia was higher in mixed STHs.
\end{abstract}

Keywords - Eosinophil, eosinophilia, Soil Transmitted Helminthiasis, single and mixed STHs

\section{INTRODUCTION}

Eosinophils frequently accumulate in tissue soon after helminth invasion. This happens also in hosts immunologically naïve to the invading parasite, a fact suggesting that eosinophils play a role in innate defence against this type of pathogen [1]. This rapid and non-spesific eosinophilic response might be a barrier limiting mechanism active against the invasion of many tissue-dwelling helminthes. Most helminth infection stimulate Th2-like T-cell responses, including stimulation of eosinophilia and of parasite-spesific as well as polyclonal $\operatorname{IgE}$ synthesis [2-4]. Eosinophils also play a role in the pathogenesis of helminth infections. Eosinophils can cause tissue damage through a number of different mechanism, including direct cytotoxicity, physical damage caused by tissue infiltration (spaceoccupying) and thromboembolic phenomena cause by eosinophil-induced hypercoagulability. However, it is the release of eosinophil granule proteins and other cytotoxic substances that has been best correlated with helminth-induced tissue damage [1], [2]. Blood eosinophilia usually is defined as eosinophilia in excess of 500 cells/ $\mu 1$ of blood. Other cut-offs for blood eosinophilia have been proposed to adjust for improved sensitivity and specificity in certain epidemiological and diagnostic settings, such as 600 eosinophils/ $\mu 1$ in tropical areas with a high prevalence of parasitic infections, or $450 / \mu 1$ in travellers returning from those areas [1], [5]. Helminth infection can cause serious acute and chronic disease, but the majority of individuals with intestinal helminth infections are asymptomatic. In highly endemics area, multiple infections with several species of intestinal helminthes and with other parasites are extremely common, especially in children and combine to result in anemia, hypoproteinemia, malnutrition and immunosuppression, causing significant chronic morbidity as well as increased morbidity and mortality of intercurent diseases such as malaria, 
pneumonia or acute diarrhea [2]. The most prevalent human helminthiasis are caused by nematode species including Soil Transmitted Helminthes (Ascaris lumbricoides, Trichuris trichiura, hookworm: Ancylostoma duodenale and Necator americanus) and filarial worms (Brugia malayi, Onchocerca volvulus and Wuchereria bancrofti), Strongyloides stercoralis and Enterobius vermicularis. Of the trematodes, Schistosoma japonicum, Schistosoma mansoni and Schistosoma haematobium and some cestodes [4]. STH are a group of parasitic nematode worms that cause infection in humans following either the ingestion of eggs or contact with larvae, which developed rapidly in the warm climate and moist soil that are frequently observed in both tropical and subtropical countries, particularly in developing countries [7]. Concomitant infections are common in nature and often involve parasites. The term concomitant infection, alternatively called mixed infection. In mixed infections the burden of one or both infectious agents may be increased, one or both may be suppressed or may be increased and the other suppressed [8]. Certain combination of helminth co-infection are more common in human populations than others, notably several nematode pairs including: A. lumbricoides and T. trichiura. A. lumbricoides and hookworm and $O$. volvulus and $T$. trichiura. Co-infection also tends to be associated with higher worm burdens than those in single species infections. A. lumbricoides-T.trichiura coinfected individuals were also to have higher IgG4; $\mathrm{IgE}$ ratio than their singly-infected counterparts [3]. This study was carried out to investigate wether eosinophil is higher in mixed STHs than in single STHs and to determine the prevalence of single and mixed STHs in the studied groups.

\section{METHOD}

Subjects of this observational cross-sectional study were children of SD Panti Asuhan AlWashliyah Pulo Brayan on August 2015. Children who had received anthelminthic drugs within three months of the study are excluded. Stool samples were investigated for STHs by Kato-katz. Then 82 stool samples positive for STHs investigated for eosinophil blood count. The stool samples positive for STHs then divided into two groups single and mixed infection. Single infection of STHs if there were only one species of STH found in stool sample and mixed infection if there were more than one species of STH found in stool sample. Each of the stool samples then classified for infection intensity by number of egg per gram (epg.). For $A$. lumbricoides was classified as light infection if 1 to 4999 epg; moderate infection 5000-49999 and heavy infection $>50000 \mathrm{epg}$. For $T$. trichiura and hookworm were classified as light infection if 1 to 999 epg; moderate infection

1000 to 9999 and heavy infection > 10000 epg [7]. Eosinophilia is defined as an increase of eosinophilic leukocytes to more than 500 cells per $\mu 1$ in peripheral blood or elevated percentage of eosinophils $>5 \%$ [1], [5].

III. RESULTS AND DISCUSSION

TABLE I

CHILDREN WITH SOIL TRANSMITTED HELMITNTHIASIS

\begin{tabular}{|c|c|c|}
\hline & n & \% \\
\hline Soil Transmitted Helminthiasis & \multicolumn{2}{|c|}{} \\
\hline single & 40 & 48,8 \\
\hline mixed & 42 & 51,2 \\
\hline Intensity & & \\
\hline light & 73 & 89 \\
\hline moderate & 6 & 7,3 \\
\hline heavy & 3 & 3,7 \\
\hline
\end{tabular}

TABLE III

EOSINOPHIL COUNT IN CHILDREN WITH SOIL TRANSMITTED HELMITNTHIASIS

\begin{tabular}{|l|c|c|}
\hline \multirow{2}{*}{} & \multicolumn{2}{|c|}{ Eosinophil } \\
\cline { 2 - 3 } & $\mathrm{n}$ & Percentage \\
\hline Soil Transmitted & & \\
\hline Normal & & 70,7 \\
\hline Increased & 24 & 29,3 \\
\hline
\end{tabular}

TABLE IIIII

MEAN OF EOSINOPHIL IN CHILDREN WITH SOIL TRANSMITTED HELMITNTHIASIS

\begin{tabular}{|l|c|}
\hline $\begin{array}{l}\text { Soil Transmitted } \\
\text { Helminthiasis }\end{array}$ & Mean of eosinophil count (\%) \\
\hline Single & 6,86 \\
\hline Mixed & 10,12 \\
\hline
\end{tabular}

The results showed from table 1 that of 82 children with STHs, 40 children $(48,8 \%)$ were single STHs and 42 children $(51,2 \%)$ were mixed STHs. Intensity of STHs were $89 \%$ light infection, 7,3\% moderate and $3,7 \%$ heavy infection. There was no significant correlation between intensity of STHs and eosinophil count. A study of Bestari et all in Jawa Tengah, Indonesia, 2015 determined that there 
was a very weak correlation between intensity of STHs and eosinophil count [9]. The wide range of egg amount may be the reason for there was no significant correlation. Mean of eosinophilia was found $6,86 \%$ with SD 3,93 on single STHs and $10,12 \%$ with SD 6,34 on mixed STHs. The study showed that eosinophilia correlated with STHs. Of 82 children suffering STHs, 70,7 \% had eosinophilia, $29,3 \%$ had normal eosinophil in their blood. A study were conducted by Matei et all in Manado, Indonesia, 2012 determine significant eosinophilia in children with STHs [10]. The abscense of eosinophilia cannot exclude these parasites. However, the incidence and extent of infection related eosinophilia do not depend only on the type, intensity and stage of infection; other factors such as individual differences in innate and adaptive immune responses, epidemiological background, age at first exposure, underlying conditions, etc are important as well. In this study eosinophil was higher in mixed STHs than in single STHs. Different with study that Sylvia et all, 2014, that there was no significant difference of eosinophil count in children with single and mixed STHs [7]. Some limitations for this study that there wss no questioner for the subjects to avoid allergies, asthma, atopic dermatitis, rheumatology, malignancy, immunodeficiency gastrointestinal which could be a factor contributing the increase of eosinophil.

\section{CONCLUSIONS}

There was a significant difference of eosinopnil value between single and mixed STHs on children of
SD Panti Asuhan Al-Jamiyatul Washliyah Pulo Brayan Medan. As conclusion in this study eosinophilia was higher in mixed STHs than in single STHs.

\section{ACKNOWLEDGMENT}

The authors are thanked for the children of SD Panti Asuhan Al-Washliyah Pulo Brayan for their participation in this study and thanked to the principals, teachers and parents for their support.

\section{REFERENCES}

[1] R. Shamri, J. J. Xenakis, L.A. Spencer, "Eosinophils in innate immunity: an evolving story", in Cell Tissue Res, vol. 347, pp: 57-83, 2011.

[2] T. Loscher and E. Saathov, "Eosinophilia during intestinal infection", in Best practice and research clinical gastroenterology, vol. 22, pp. 511536, 2008.

[3] L. Huang and J.A. Appleton, "Eosinophils in Helminth Infection: Defenders and Dupes", in Trends in Parasitology, vol. 32, pp: 800-807, Okt. 2016.

[4] R.M. Maizles and M. Yazdanbakhsh, "Immune regulation by helminth parasites: cellular and molecular mechanisms", in Immunology, vol. 3, pp: 733-744, 2003.

[5] J.S. Coronas, M.T.C. Fernandez, J.V. Villegas, M.J.S. Perez, A.B.L. Serrano, I.P. Camacho, M.I.C. Barrera, F. Cobo, "Evaluation of eosinophilia in immigrants in Southern Spain using tailored sreening and treatment protocols: A prospective study", in Travel medicine and infectious disease, vol. 13, pp 315-321, 2015.

[6] C.D. Bourke, R.M. Maizels, F. Mutapi, "Acquired immune heterogeneity and its sources in human helminth infection", in Parasitology, vol. 138, pp: 138-159, 2011

[7] S. Jierro, M. Ali, S. Pasaribu, A.P. Pasaribu, "Correlation between eosinophil count and soil transmitted helminth infection in children", in Asian Pac J Trop Dis, vol. 5, pp: 813-816, 2015.

[8] F.E.G. Cox, "Concomitants infection, parasites and immune response", in Parasitology, vol. 122, pp: 23-28, 2001.

[9] R.S. Bestari, Supargiyono, Sumarni dan Suyoko, "Derajad eosinophilia pada penderita Soil Transmitted Helminth(STH)",dalam Biomedika, vol. 7, hal: 27-35, Agustus 2015.

[10] Y.T. Matei, N. Rampengan, S.M. Warouw, "Hubungan infestasi cacing yang ditularkan melalui tanah dan eosinophilia pada siswa SD GMIM BUHA Manado", dalam Jurnal e-Biomedik (eBM), vol. 1, hal: 651-655, Maret 2013. 